\title{
Empirical Study on the Operational Decisions of Taiwanese Enterprises
}

\author{
Shu-Hsing Hsu \\ Graduate Institute of East Asian Studies, National Chengchi University, Chinese Taipei \\ Email: hsing0099@gmail.com
}

Received 25 September 2014; revised 26 October 2014; accepted 7 November 2014

Copyright (C) 2014 by author and Scientific Research Publishing Inc.

This work is licensed under the Creative Commons Attribution International License (CC BY).

http://creativecommons.org/licenses/by/4.0/

c) (i) Open Access

\begin{abstract}
This study addresses the lack of empirical analysis on Taiwanese enterprises operating in China. A questionnaire-based survey was used to assess the business decisions of Taiwanese companies operating in the Chinese cities of Dongguan, Shenzhen, Shanghai and Kunshan. The empirical results indicate that direct input costs and business types have an appreciable impact on the decision of mainland-based Taiwanese enterprises to relocate operations. Additionally, government financing, administrative ability, and improvement in operating costs can effectively reduce the likelihood of market exit by a Taiwanese enterprise.
\end{abstract}

\section{Keywords}

\section{Taiwanese Enterprises, Operational Decision, Probit}

\section{Introduction}

Statistical data published by the World Bank indicates that the global economy grew at an average rate of 3.14\%, $2.74 \%$, and $2.71 \%$ in the three 10 -year periods from 1980 to 2000 . In the same period, China's economy expanded by $9.75 \%, 9.99 \%$, and $10.29 \%{ }^{1}$, underscoring the rapid rate of growth and development of the mainland economy. The gap between China's economic growth rate and the global average has shrunk since China's accession to the World Trade Organization (WTO) at the end of 2001. During these decades, mainland China was perceived as the "factory of the world". Trade across the Taiwan Strait has intensified since China first opened up in 1979. Statistics reported by Taiwan's Ministry of Finance indicate that Taiwan's exports to China in 2003 amounted to US\$35.36 billion or about 24.52\% of Taiwan’s total exports that year. By 2010, exports to China absorbed over $40 \%$ of Taiwan's total exports. Since then, economic and trade ties across the strait have grown and intensified. Taiwanese companies in mainland China have played an important role in this economic process.

${ }^{1}$ Refer to the World Bank website: http://data.worldbank.org/indicator/NY.GDP.MKTP.KD.ZG. 
Yet there is currently a dearth of literature with empirical studies on the operating status of Taiwanese enterprises in mainland China. This owes largely to the lack of available statistics, as well as to the complications in sifying related statistical research due to the diverse business scopes of Taiwanese companies, ranging from garments, semiconductors and electronic components to mobile phone and other sectors.

The U.S. subprime mortgage crisis in July 2007 sparked global financial turmoil. The world economic climate also affected economic production in China's coastal areas, where the main production bases of Taiwanese companies are concentrated. What factors influence the business decisions of Taiwanese companies in China? And will these companies continue operating, transform their business or exit the market when confronted by cost pressures or the effects of local government policy? These are all themes explored in this study. To avoid obstacles in the statistical data related to industry and product categories, this study used a questionnaire method to analyze the business conditions in mainland cities with Taiwanese enterprise clusters, including Dongguan, Shenzhen, Shanghai and Kunshan. The study investigated the production status of Taiwanese enterprises businesses and whether local government policy assistance affected the decision of these companies to continue operations in the area or to relocate.

The empirical results show that cost pressures and availability of government policy assistance affected whether Taiwanese enterprises continued operations or relocated. It was also found that local governments provided policy assistance with higher incentives for potential industries or specific companies within their jurisdiction.

This paper is structured as follows: The second section describes the relevant literature; the third section discusses the research data, the fourth section introduces the estimated model and the next part describes empirical analysis results; finally the last section presents conclusions.

\section{Literature Review}

The institutional environment is an important factor in the operational processes of companies. The central and local government therefore plays a very important role in the decision of companies to relocate. ${ }^{2}$ Weingast [1], Oyelaran-Oyeyinka and Rasiah [2] emphasize that the government often plays a critical role in industrial upgrading in East Asia. Wu [3] considered that the devolution of power from the central government in China incentivizes local governments to increase revenue momentum and sustain economic development.

Total Taiwanese investment in mainland China has increased steadily with China's rise. There has also been a steady, phased escalation in the types of industries receiving investment. Each industry has different motivations for investing in mainland China, such as pursuit of low-cost labor, the huge consumer market, seeking a complementary industrial environment, or responding to environmental protection demands on production at home. Different levels of attention are placed on factors from markets to production costs. There are also major differences between industries in terms of the importance of local conditions. This in turn results in differences between the degree of localization in the production networks of Taiwanese enterprises. The political situation in mainland China changed after 1978. China's neighbors, Japan and the Four Asian Tigers, gave emerging industrial countries a model for successful economic development, and prompted mainland China to promote an export-oriented economy. Reforms and opening measures were promoted in tandem with export-oriented policies.

The mainland government started out with trial points to learn from experience. Four special economic zones were first opened up in Fujian and Guangdong provinces near Taiwan and Hong Kong, respectively. Seaboard cities and other coastal provinces were subsequently opened up to ascertain the feasibility of opening up the entire mainland area in the future. Due to the initially limited number of opened areas and immature investment environment in the mainland, most Taiwanese companies are concentrated in Guangdong and Fujian. This development pattern has also lifted the living standards and salary levels in the coastal areas above comparable levels in interior regions.

Taiwanese companies have faced increasingly adverse conditions at home due to rising production costs, overall environmental demands on factories, and appreciation of the NT dollar in context of the international economic environment [5]. This trend has forced Taiwanese companies to look outward for a new production hinterland. The cheap factors of production in the mainland have earned favor among Taiwanese companies and enabled Taiwan to reduce its high production costs [6]. After 2000, the pattern of Taiwanese enterprise investment in the mainland underwent a change. Whereas small and medium enterprises (SMEs) drove investment in

${ }^{2}$ Hamilton and Biggart [4]. 
the early stage, large enterprises now were beginning to invest in the mainland. Electronic, information, precision machinery and petrochemical industries with vertically integrated systems also invested in the mainland, spurring the rise of a new wave of Taiwan business networks.

Taiwan business investment in mainland Chinese provinces is now positively correlated to total foreign direct investment and industrialization level, with most investment concentrated in the coastal provinces. As to the clustering phenomenon of such investment, Hamilton ed. [7] observes that enterprise clusters can form both interpersonal and inter-company cooperative networks to overcome barriers related to a systematic lack of game rules or to compensate for the insufficient organizational resources of SMEs. Regardless of their size, Taiwan companies depend on cooperative networks to achieve external economic effects. This is particularly true of SMEs. Due to efficiencies beyond the reach of large enterprises, SMEs can achieve a mutually beneficial external economy through integration within cooperative networks.

\section{Data}

For this study, a questionnaire survey was conducted looking at Taiwanese enterprises by type, location (Yangtze River Delta or other areas), business scale, and operational difficulties encountered (foreign trade, land, labor, production and marketing, regulations, and taxation), local government measures (financial aid, tax subsidies, operating cost improvements, concession and incentive policies, etc.). This data was collected to investigate the relationship between firms' production behavior, the quality of circumstances on the business location and the efficiency of the government's merchant movement. The main regions surveyed include the mainland cities of Dongguan, Shenzhen, Shanghai and Kunshan, where large numbers of Taiwanese businesses are located. Secondly, Taiwanese businesspeople have a similar cultural background to their mainland counterparts, lowering the cultural obstacles compared to hurdles faced by foreign companies in this regard. The Taiwan Business Association chapters in these cities were commissioned to distribute and collect the questionnaires and conduct interviews. The total number of questionnaire samples was 314, as detailed in Table 1.

In Table 1, we can find that more than half of the firms are located in the Yangtze River delta and surrounding area (0.519) and $42.8 \%$ are located in areas with Taiwan business clusters. Second, only $14.3 \%$ samples are joint venture. In terms of operating issues, more than $80 \%$ of the enterprises reported facing employment difficulties. In addition, more than $50 \%$ of the companies noted the affects of regulatory and tax difficulties. In terms

\section{Table 1. Descriptive Statistics.}

\begin{tabular}{|c|c|c|c|c|}
\hline Variable & Mean & Stedv & Min & Max \\
\hline Relocate & 1.393 & 0.875 & 0 & 1 \\
\hline Joint venture & 0.143 & 0.351 & 0 & 1 \\
\hline Yangtze River delta and surrounding area & 0.519 & 0.500 & 0 & 1 \\
\hline Located at Taiwan business cluster area & 0.428 & 0.495 & 0 & 1 \\
\hline Annual turnover & 3.863 & 1.248 & 0 & 5 \\
\hline Employment difficulties & 0.808 & 0.394 & 0 & 1 \\
\hline Land difficulties & 0.497 & 0.501 & 0 & 1 \\
\hline Regulatory difficulties & 0.684 & 0.465 & 0 & 1 \\
\hline Tax difficulties & 0.642 & 0.480 & 0 & 1 \\
\hline Production and marketing difficulties & 0.464 & 0.499 & 0 & 1 \\
\hline Foreign trade difficulties & 0.466 & 0.499 & 0 & 1 \\
\hline Gov’t action: Financing & 0.411 & 0.492 & 0 & 1 \\
\hline Gov't action: Tax burden & 0.324 & 0.468 & 0 & 1 \\
\hline Gov't action: Administrative ability & 0.297 & 0.457 & 0 & 1 \\
\hline Gov't action: Improvement in operating costs & 0.320 & 0.467 & 0 & 1 \\
\hline Gov't action: Concession and incentive policies & 0.307 & 0.462 & 0 & 1 \\
\hline Social security & 0.501 & 0.501 & 0 & 1 \\
\hline Level of government control over labor rules & 0.196 & 0.587 & 0 & 2 \\
\hline Labor-intensive industries & 0.227 & 0.420 & 0 & 1 \\
\hline
\end{tabular}

Note: 314 Samples. 
of government policy, These enterprises were primarily concerned with financial and tax burdens.

\section{Model}

The explained variable in the empirical study is whether Taiwanese companies choose to relocate their operations. The data is a categorical dummy variable and is also known in microeconometric theory as a limited data or binary choice model. Empirical data is normally analyzed under a Probit or Logit model generally. The Probit model is used for assessment in this paper according to the following model:

$$
\text { Decision relocate } \vee \text { not }=\alpha_{0}+\beta X_{i}+\varepsilon_{i}
$$

The " $i$ " in formula (1) represents individual Taiwanese companies; $X$ is a qualitative variable; $\varepsilon$ represents random interference; and the beta coefficient estimate value captures the impact result. For the purpose of estimation, the explained variables have a value of either 0 or 1 and the interference term $\varepsilon$ therefore obeys this binomial distribution. In formula (1) for example, the probability distribution $P$ can be determined as follows given the explanatory variables:

$$
\left\{\begin{array}{l}
P(\text { company relocation } \mid F G, X)=F(X, \alpha) \\
1-P(\text { company relocation } \mid F G, X)=1-F(X, \alpha)
\end{array}\right.
$$

Here, $F(X, \alpha)$ is a cumulative density function that can also represent the probability value that a Taiwanese company will relocate as:

$$
P(\text { market exit } \mid F G, X)=F(X, \alpha)=\Phi\left(X^{\prime} \alpha\right) \equiv \int_{-\infty}^{X^{\prime} \alpha} \varnothing(t) \mathrm{d} t
$$

The large sample estimate assumes that the data obeys the statistical standard normal distribution and that individual samples are mutually independent. The $\log$ likelihood function $\ln L$ is defined as follows:

$$
\ln L=\sum_{i=1}^{n} n_{i}\left\{p_{i} \ln F(X, \alpha)+\left(1-p_{i}\right) \ln [1-F(X, \alpha)]\right\}
$$

With the maximum likelihood method, it is possible to estimate the impact and marginal effect of each explanatory variable on the probability that the respondent company will continue operations. The assessment results are presented in Table 2.

\section{Empirical Result}

In Table 2, the empirical data indicates that joint venture (JV) type Taiwanese enterprises are less willing to relocate (with an estimated value of 0.435). This finding suggests that such companies are likely to face higher operational integration problems than are their sole proprietorship counterparts. Market exit would likely affect the company's integrated layout or lead to cost-related losses. Hence, these companies have less incentive to relocate than do sole proprietorships. In terms of enterprise scale, assessments using two types of model show that the amount of annual turnover had no statistically significant impact on whether an enterprise relocated.

Among operational difficulties, it was found that Taiwanese companies facing employment difficulties had an incentive to relocate (0.896) as barriers to input factors strengthened the decision to move. Social security variables are noteworthy in that the estimated results indicate that companies pressured to pay social insurance are inclined to relocate by a statistically significant factor (0.720). Economic development enhances the living standard and has also given rise to demand for social insurance and social security. This in turn has heightened employment difficulties for companies in areas such as wage contracts, workplace safety, and labor disputes. Finally, Table 2 further analyzes government actions. The assessment indicates that governments can significantly reduce the willingness of Taiwanese enterprises to relocate through financial aid, administrative orders and policy measures to improve the operating costs of Taiwanese businesses. These estimated results suggest that the government may build or maintain a business-friendly environment.

Among the estimations for different sample groups, evidence from the manufacturing industry samples showed that labor difficulties (0.955), foreign trade difficulties $(-0.413)$, and social security pressure $(0.695)$ encouraged companies to relocate. Estimations for the Yangtze River delta and surrounding area showed that JV enterprises $(-1.111)$ and companies facing employment difficulties $(-0.799)$ have a harder time relocating. This likely reflects the fact that the production process is a short-term process in economics. In the short-term, firms 
Table 2. Estimation result.

\begin{tabular}{|c|c|c|c|c|c|c|}
\hline \multirow{3}{*}{$\begin{array}{c}\text { Independent variable } \\
\text { Probit }\end{array}$} & \multicolumn{6}{|c|}{ Relocate } \\
\hline & \multicolumn{2}{|c|}{ All samples } & \multicolumn{2}{|c|}{$\begin{array}{l}\text { Manufacturing industry } \\
\text { samples }\end{array}$} & \multicolumn{2}{|c|}{$\begin{array}{l}\text { Yangtze River Delta and } \\
\text { surrounding area }\end{array}$} \\
\hline & Coefficient & Standard error & Coefficient & Standard error & Coefficient & Standard error \\
\hline Joint venture & $-0.435^{*}$ & $(0.238)$ & -0.101 & $(0.292)$ & $-1.111^{* * *}$ & $(0.400)$ \\
\hline Yangtze River delta and surrounding area & 0.048 & $(0.179)$ & 0.063 & $(0.214)$ & & \\
\hline Located at Taiwan business cluster area & 0.086 & $(0.169)$ & 0.133 & $(0.202)$ & 0.181 & $(0.230)$ \\
\hline Annual turnover & -0.013 & $(0.071)$ & -0.102 & $(0.086)$ & -0.144 & $(0.094)$ \\
\hline Employment difficulties & $0.896^{* * *}$ & $(0.271)$ & $0.955^{* * *}$ & $(0.335)$ & $-0.799^{* *}$ & $(0.394)$ \\
\hline Land difficulties & -0.167 & $(0.199)$ & -0.189 & $(0.233)$ & -0.197 & $(0.278)$ \\
\hline Regulatory difficulties & $-0.706^{*}$ & $(0.363)$ & -0.699 & $(0.453)$ & -0.639 & $(0.592)$ \\
\hline Tax difficulties & -0.211 & $(0.216)$ & -0.3 & $(0.260)$ & -0.201 & $(0.304)$ \\
\hline Production and marketing difficulties & 0.088 & $(0.212)$ & -0.052 & $(0.259)$ & 0.012 & $(0.288)$ \\
\hline Foreign trade difficulties & -0.257 & $(0.213)$ & $-0.413^{*}$ & $(0.254)$ & -0.112 & $(0.290)$ \\
\hline Gov’t action: Financing & $-0.689^{*}$ & $(0.403)$ & -0.38 & $(0.443)$ & -0.178 & $(0.569)$ \\
\hline Gov’t action: Taxation & 0.411 & $(0.418)$ & -0.044 & $(0.534)$ & 0.255 & $(0.509)$ \\
\hline Gov’t action: Administrative ability & $-0.983^{*}$ & $(0.582)$ & -0.058 & $(0.676)$ & -0.211 & $(0.741)$ \\
\hline $\begin{array}{l}\text { Gov’t action: Improvement in } \\
\text { operating costs }\end{array}$ & $-1.418^{* *}$ & $(0.713)$ & 0.600 & $(0.814)$ & 0.803 & $(1.048)$ \\
\hline $\begin{array}{l}\text { Gov't action: Concession and } \\
\text { incentive policies }\end{array}$ & -0.413 & $(0.465)$ & -0.478 & $(0.501)$ & -0.799 & $(0.728)$ \\
\hline Social security & $0.720^{* *}$ & $(0.291)$ & $0.695^{*}$ & $(0.364)$ & 0.56 & $(0.472)$ \\
\hline $\begin{array}{l}\text { Level of government control } \\
\text { over labor rules }\end{array}$ & -0.09 & $(0.117)$ & 0.073 & $(0.131)$ & 0.005 & $(0.153)$ \\
\hline Labor-intensive industries & 0.266 & $(0.189)$ & 0.29 & $(0.217)$ & 0.144 & $(0.269)$ \\
\hline Constant term & $0.777^{* *}$ & $(0.344)$ & $1.180^{* * *}$ & $(0.449)$ & $1.037^{* *}$ & $(0.484)$ \\
\hline Log-likelihood & -150.951 & & -108.333 & & -83.998 & \\
\hline Number of samples & 314 & & 248 & & 165 & \\
\hline
\end{tabular}

Source: Data compiled by this study. Note: ${ }^{* * *},{ }^{* *},{ }^{*}$ indicate $1 \%, 5 \%$ and $10 \%$ level of significance, respectively.

usually face problems related to fixed inputs or unadjusted production. Since employment is a labor input problem and an enterprise cannot easily change its input structure in the short term, the enterprise is not likely to make a market-exit move.

Compared with different estimations, the joint venture model and employment difficulties both significantly affect entrepreneurs' decision on whether to relocate or not. The former indicates that the joint venture model brings additional considerations in the discussion of whether to stay or move. Employment difficulties strictly reflect operational costs and reducing the cost of labor inputs is a key factor in the firms' decision to relocate or not.

\section{Conclusions}

In this study we investigated the production status of Taiwanese enterprises businesses and whether local government policy assistance affected the decision of these companies to continue operations in the area or to relocate. The purpose of our study is to focus on the relationship between the enterprises' production behavior, the quality of business or market situation on the business location and the efficiency of the government's merchant movement.

Empirically we find that the main factor affecting the intention of Taiwanese companies to relocate is the company's operating costs. However, related government measures, such as improvement in operating costs, capital subsidies, and administrative capacity, all significantly reduce the intention of companies to relocate. In fact this result differs from company operations and government measures in Europe and the United States, where the governments in general do not lightly offer policy assistance to specific industries or companies. This 
was particularly evident during the 2008 financial crisis, during which the U.S. government did not provide administrative assistance to Lehman Brothers, Fannie Mae or other enterprises. In contrast, for example, the government of Taiwan has provided subsidies to Acer Computer, highlighting differences between Eastern and Western society in the handling of such situations. This phenomenon can perhaps be explained in terms of differences in economic development. Relative to Europe and the United States, mainland China is still a developing economy. Local governments may hope they can locally foster nationally or provincially important industries and companies and hence are more incentivized to provide policy assistance to potential industries or specific companies within their jurisdictions.

Finally, we discuss the limitation on this study. Although our investigation seeks to identify the factors affecting the operational choices of Taiwanese companies, there is a need to expand the empirical data and survey areas. Due to factors such as trade secrets and market competitions, businesspeople may fail to disclose private information about their operation. Further research may consider applying the hedonic approach to evaluate and estimate this information or indirect effects.

\section{References}

[1] Weingast, B.R. (1997) The Political Foundations of Democracy and the Rule of Law. American Political Science Review, 91, 245-263. http://dx.doi.org/10.2307/2952354

[2] Oyelaran-Oyeyinka, O. and Rasiah, R. (2009) Uneven Paths of Development: Innovation and Learning in Asia and Africa. Edward Elgar Publishing, Massachusetts.

[3] Wu, C.M. (2009) China Model? Or Multiple and Complex System Shaped Configuration? Taiwanese Sociology, 18, 1-3.

[4] Hamilton, G.G. and Biggart, N.W. (1988) Market, Culture and Authority: A Comparative Analysis of Management and Organization in the Far East. American Journal of Sociology, 94, 52-94.

[5] Luo, Q. and Howe, C. (1993) Direct Investment and Economic Integration in the Asia Pacific: The Case of Taiwanese Investment in Xiamen. The China Quarterly, 136, 746-769. http://dx.doi.org/10.1017/S030574100003232X

[6] Kojima, K. (1978) Direct Foreign Investment: A Japanese Model of Multinational Business Operation. Praeger Publishers, New York.

[7] Hamilton, G.G. (1996) Asian Business Networks. Vol. 64, Walter de Gruyter, Berlin. http://dx.doi.org/10.1515/9783110888317 
Scientific Research Publishing (SCIRP) is one of the largest Open Access journal publishers. It is currently publishing more than 200 open access, online, peer-reviewed journals covering a wide range of academic disciplines. SCIRP serves the worldwide academic communities and contributes to the progress and application of science with its publication.

Other selected journals from SCIRP are listed as below. Submit your manuscript to us via either submit@scirp.org or Online Submission Portal.
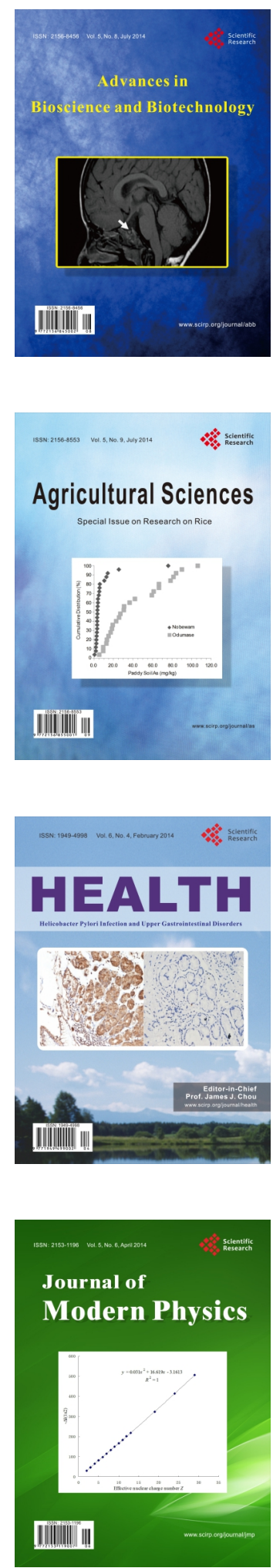
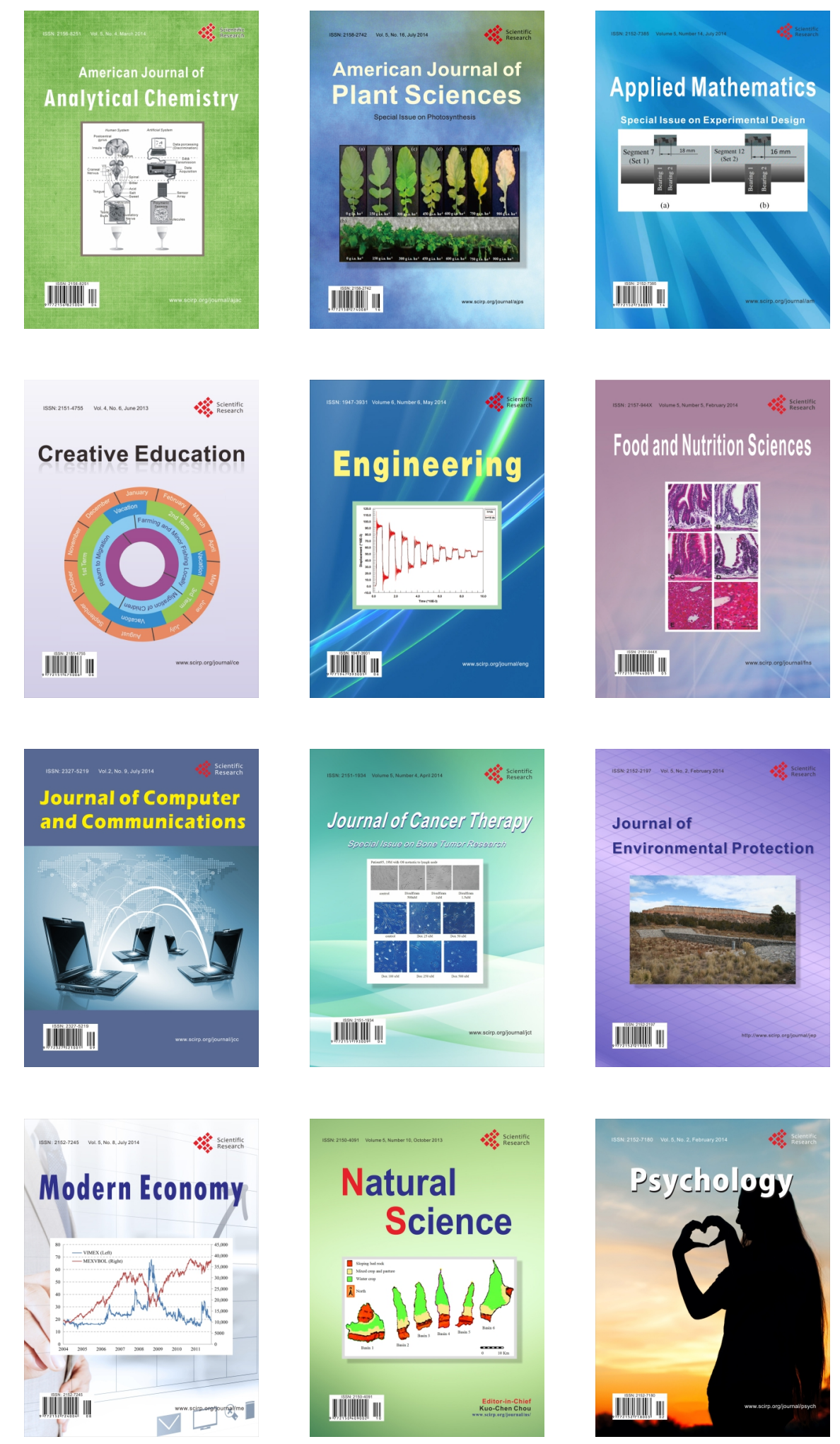